\title{
Front Matter: Volume 8188
}

, "Front Matter: Volume 8188," Proc. SPIE 8188, Millimetre Wave and Terahertz Sensors and Technology IV, 818801 (27 October 2011); doi: 10.1117/12.917111

SPIE. Event: SPIE Security + Defence, 2011, Prague, Czech Republic 


\section{PROCEEDINGS OF SPIE}

\section{Millimetre Wave and Terahertz Sensors and Technology IV}

Keith A. Krapels

Neil A. Salmon

Eddie Jacobs

Editors

19-20 September 2011

Prague, Czech Republic

Sponsored and Published by

SPIE

Volume $\mathbf{8 1 8 8}$ 
The papers included in this volume were part of the technical conference cited on the cover and title page. Papers were selected and subject to review by the editors and conference program committee. Some conference presentations may not be available for publication. The papers published in these proceedings reflect the work and thoughts of the authors and are published herein as submitted. The publisher is not responsible for the validity of the information or for any outcomes resulting from reliance thereon.

Please use the following format to cite material from this book:

Author(s), "Title of Paper," in Millimetre Wave and Terahertz Sensors and Technology IV, edited by Keith A. Krapels, Neil A. Salmon, Eddie Jacobs, Proceedings of SPIE Vol. 8188 (SPIE, Bellingham, WA, 2011) Article CID Number.

ISSN 0277-786X

ISBN 9780819488169

Published by

SPIE

P.O. Box 10, Bellingham, Washington 98227-0010 USA

Telephone +1 3606763290 (Pacific Time) · Fax +1 3606471445

SPIE.org

Copyright (C) 2011, Society of Photo-Optical Instrumentation Engineers

Copying of material in this book for internal or personal use, or for the internal or personal use of specific clients, beyond the fair use provisions granted by the U.S. Copyright Law is authorized by SPIE subject to payment of copying fees. The Transactional Reporting Service base fee for this volume is $\$ 18.00$ per article (or portion thereof), which should be paid directly to the Copyright Clearance Center (CCC), 222 Rosewood Drive, Danvers, MA 01923. Payment may also be made electronically through CCC Online at copyright.com. Other copying for republication, resale, advertising or promotion, or any form of systematic or multiple reproduction of any material in this book is prohibited except with permission in writing from the publisher. The CCC fee code is 0277-786X/11/ \$18.00.

Printed in the United States of America.

Publication of record for individual papers is online in the SPIE Digital Library.

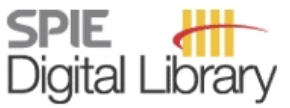

SPIEDigitalLibrary.org

Paper Numbering: Proceedings of SPIE follow an e-First publication model, with papers published first online and then in print and on CD-ROM. Papers are published as they are submitted and meet publication criteria. A unique, consistent, permanent citation identifier (CID) number is assigned to each article at the time of the first publication. Utilization of CIDs allows articles to be fully citable as soon as they are published online, and connects the same identifier to all online, print, and electronic versions of the publication. SPIE uses a six-digit CID article numbering system in which:

- The first four digits correspond to the SPIE volume number.

- The last two digits indicate publication order within the volume using a Base 36 numbering system employing both numerals and letters. These two-number sets start with $00,01,02,03,04$, $05,06,07,08,09,0 A, 0 B \ldots 0 Z$, followed by 10-1Z, 20-2Z, etc.

The CID number appears on each page of the manuscript. The complete citation is used on the first page, and an abbreviated version on subsequent pages. Numbers in the index correspond to the last two digits of the six-digit CID number. 


\section{Contents}

vii Conference Committee

\section{SESSION 1 SYSTEMS: PASSIVE IMAGERS AND SPECTROMETERS I}

818802 Investigation of security related fully polarimetric signatures of radiometer measurements at W band (Invited Paper) [8188-01]

S. Dill, M. Peichl, D. Rudolf, Deutsches Zentrum für Luft- und Raumfahrt e.V. (Germany)

818803 Reducing the acquisition time in a single sensor passive millimetre wave (PMMW) imaging system utilizing compressive sensing [8188-02]

J. B. Nogueira-Nine, R. A. Stirling-Gallacher, Sony Deutschland GmbH (Germany)

818805 First video rate imagery from a 32 -channel $22-\mathrm{GHz}$ aperture synthesis passive millimetre wave imager [8188-04]

N. A. Salmon, QinetiQ Ltd. (United Kingdom); R. Macpherson, Radio Smith (United Kingdom);

A. Harvey, Heriot-Watt Univ. (United Kingdom); P. Hall, Birmingham Univ. (United Kingdom);

S. Hayward, QinetiQ Ltd. (United Kingdom); P. Wilkinson, C. Taylor, The Univ. of Manchester

(United Kingdom)

\section{SESSION 2 SYSTEMS: PASSIVE IMAGERS AND SPECTROMETERS II}

818806 Design of a distributed aperture millimeter-wave imaging system for "see-through" imaging in rotary craft induced degraded visual environments (Invited Paper) [8188-05]

R. D. Martin, C. A. Schuetz, T. E. Dillon, D. G. Mackrides, P. Yao, Phase Sensitive Innovations, Inc. (United States); S. Shi, D. W. Prather, Univ. of Delaware (United States)

818808 Minimising the costs of next generation aperture synthesis passive millimetre wave imagers [8188-07]

N. A. Salmon, QinetiQ Ltd. (United Kingdom); P. N. Wilkinson, C. T. Taylor, M. Benyezzar, The Univ. of Manchester (United Kingdom)

\section{SESSION 3 ACTIVE SYSTEMS: IMAGERS AND RADARS}

818809 Standoff imaging of a masked human face using a $670 \mathrm{GHz}$ high resolution radar (Invited Paper) [8188-08]

J. Kjellgren, J. Svedin, Swedish Defence Research Agency (Sweden); K. B. Cooper, Jet

Propulsion Lab. (United States) 
$8188 \mathrm{OA}$ Super resolution and optical properties of $\mathrm{THz}$ double row array based on inexpensive Glow Discharge Detector (GDD) pixels [8188-09]

A. Abramovich, Ariel Univ. Ctr. of Samaria (Israel); N. S. Kopeika, Ben-Gurion Univ. of the Negev (Israel); D. Rozban, A. Levanon, Ben-Gurion Univ. of the Negev (Israel) and Ariel Univ. Ctr. of Samaria (Israel); M. Shilemay, Ariel Univ. Ctr. of Samaria (Israel); A. Akram, Ben-Gurion Univ. of the Negev (Israel) and Ariel Univ. Ctr. of Samaria (Israel); H. Joseph, Ben-Gurion Univ. of the Negev (Israel); O. Yadid-Pecht, Univ. of Calgary (Canada); A. Belenky, Ben-Gurion Univ. of the Negev (Israel)

8188 OC Active THz imaging system to measure water content evolution in leaves [8188-11] D. Ełayo, J. C. Iriarte, I. Palacios, I. Ederra, R. Gonzalo, Public Univ. of Navarra (Spain)

8188 0D Active millimeter-wave imaging system for material analysis and object detection [8188-12] C. Zech, Fraunhofer Institute for Applied Solid State Physics (Germany) and Karlsruhe Institute of Technology (Germany); A. Hülsmann, Fraunhofer Institute for Applied Solid State Physics (Germany); I. Kallfass, Fraunhofer Institute for Applied Solid State Physics (Germany) and Karlsruhe Institute of Technology (Germany); A. Tessmann, M. Zink, M. Schlechtweg, A. Leuther, Fraunhofer Institute for Applied Solid State Physics (Germany); O. Ambacher, Fraunhofer Institute for Applied Solid State Physics (Germany) and Univ. of Freiburg (Germany)

\section{SESSION 4 DEVICES}

$8188 \mathrm{OE}$ Development and characterization of $\mathrm{LiNbO}_{3}$ electro-optic phase modulator at $220 \mathrm{GHz}$ for millimeter-wave imaging system (Invited Paper) [8188-13]

J. Macario, Univ. of Delaware (United States); C. A. Schuetz, P. Yao, Phase Sensitive Innovations, Inc. (United States); S. Shi, D. W. Prather, Univ. of Delaware (United States)

8188 OF 270GHz SiGe BiCMOS manufacturing process plafform for mmWave applications [8188-14] A. Kar-Roy, E. J. Preisler, G. Talor, Z. Yan, R. Booth, J. Zheng, S. Chaudhry, D. Howard, M. Racanelli, TowerJazz (United States)

8188 OG Type-II InAs/GalnSb superlattices for terahertz range photodetectors [8188-15] M. Patrashin, I. Hosako, K. Akahane, National Institute of Information and Communications Technology (Japan)

\section{SESSION 5 SIGNATURES, INTERPRETATION, AND SYSTEM PERFORMANCES}

8188 ol Resolution capability comparison of infrared and terahertz imagers (Invited Paper) [8188-17]

A. Bergeron, L. Marchese, É. Savard, L. LeNoc, M. Bolduc, M. Terroux, D. Dufour, INO (Canada); D. Tang, Dept. of National Defence (Canada); F. Châteauneuf, H. Jerominek, INO (Canada)

$8188 \mathrm{~J} \mathrm{Enhanced} \mathrm{terahertz} \mathrm{imaging} \mathrm{system} \mathrm{performance} \mathrm{analysis} \mathrm{and} \mathrm{design} \mathrm{tool} \mathrm{for} \mathrm{concealed}$ weapon identification [8188-18]

S. R. Murrill, U.S. Army Research Lab. (United States); C. C. Franck, CACl Technologies, Inc. (United States); R. L. Espinola, U.S. Army Night Vision and Electronic Sensors Directorate (United States); D. T. Petkie, Wright State Univ. (United States); F. C. De Lucia, The Ohio State Univ. (United States); E. L. Jacobs, The Univ. of Memphis (United States) 
8188 OK New super-resolution ranging technique for FMCW radar systems [8188-19]

M. Testar, R. Stirling-Gallacher, Sony Deutschland GmbH (Germany)

$8188 \mathrm{OL}$ Millimetre radar threat level evaluation (MiRTLE) at standoff ranges [8188-20]

S. W. Harmer, N. Bowring, D. Andrews, N. Rezgui, M. Southgate, Manchester Metropolitan Univ. (United Kingdom)

$81880 \mathrm{M}$ Comparison of schemes for active sub-millimeter wave imaging [8188-21]

O. Furxhi, E. L. Jacobs, The Univ. of Memphis (United States)

$81880 \mathrm{~N} \quad$ Explosives characterization in terahertz range [8188-22]

I. Maestrojuán, I. Palacios, D. Ełayo, J. C. Iriarte, J. Teniente, I. Ederra, R. Gonzalo, Public Univ. of Navarra (Spain)

POSTER SESSION

818800 Feature extraction technique to reduce dimensionality of the acquired THz spectra response [8188-23]

R. Ryniec, M. Szustakowski, P. Zagrajek, M. Piszczek, Military Univ. of Technology (Poland)

8188 OP Low cost THz heterodyne detection by miniature neon indicator lamp glow discharge detectors [8188-24]

H. Joseph, N. S. Kopeika, Ben-Gurion Univ. of the Negev (Israel); A. Abramovich, Ariel Univ. Ctr. of Samaria (Israel); A. Akram, A. Levanon, D. Rozban, Ben-Gurion Univ. of the Negev (Israel) and Ariel Univ. Ctr. of Samaria (Israel)

Author Index 
Downloaded From: https://www.spiedigitallibrary.org/conference-proceedings-of-spie on 26 Apr 2023

Terms of Use: https://www.spiedigitallibrary.org/terms-of-use 


\title{
Conference Committee
}

\author{
Symposium Chairs
}

David H. Titterton, Defence Science and Technology Laboratory (United Kingdom)

Reinhard R. Ebert, Fraunhofer-Institut für Optronik, Systemtechnik und Bildauswertung (Germany)

Čestmír Vlček, University of Defence (Czech Republic)

Conference Chairs

Keith A. Krapels, U.S. Army Night Vision \& Electronic Sensors Directorate (United States)

Neil A. Salmon, QinetiQ Ltd. (United Kingdom)

Eddie Jacobs, The University of Memphis (United States)

Programme Committee

Amir Abramovich, Ariel University Center of Samaria (Israel)

Nicholas J. Bowring, Manchester Metropolitan University (United Kingdom)

Markus Peichl, Deutsches Zentrum für Luft- und Raumfahrt e.V. (Germany)

Douglas T. Petkie, Wright State University (United States)

Christopher A. Schuetz, Phase Sensitive Innovations, Inc. (United States)

\section{Session Chairs}

1 Systems: Passive Imagers and Spectrometers I

Nicholas J. Bowring, Manchester Metropolitan University (United

Kingdom)

Neil A. Salmon, QinetiQ Ltd. (United Kingdom)

2 Systems: Passive Imagers and Spectrometers II

Markus Peichl, Deutsches Zentrum für Luft- und Raumfahrt e.V.

(Germany)

Eddie Jacobs, The University of Memphis (United States)

3 Active Systems: Imagers and Radars

Neil A. Salmon, QinetiQ Ltd. (United Kingdom)

Christopher A. Schuetz, Phase Sensitive Innovations, Inc. (United States)

Nicholas J. Bowring, Manchester Metropolitan University (United Kingdom) 
Devices

Nicholas J. Bowring, Manchester Metropolitan University (United

Kingdom)

Christopher A. Schuetz, Phase Sensitive Innovations, Inc. (United States)

$5 \quad$ Signatures, Interpretation, and System Performances

Neil A. Salmon, QinetiQ Ltd. (United Kingdom)

Markus Peichl, Deutsches Zentrum für Luft- und Raumfahrt e.V. (Germany) 